\title{
5. PALYNOFACIES AND THERMAL MATURATION ANALYSIS OF SEDIMENTS FROM THE NANKAI TROUGH ${ }^{1}$
}

\author{
John V. Firth ${ }^{2}$
}

\begin{abstract}
Analysis of the palynofacies and miospore thermal alteration indices (TAI) of sediments from ODP Site 808 in the Nankai Trough was undertaken to determine (1) the source, depositional environment, and diagenesis of organic matter in the accreted sediments, and (2) the thermal structure and history of the prism and its relationship to fluid flow.

Using the Hartax classification system, two palynofacies were recognized in the sedimentary sequence. Facies 1 occurs within the upper $600 \mathrm{~m}$ of trench-wedge turbidites (sedimentation rate $>1 \mathrm{~km} / \mathrm{m} . \mathrm{y}$.) and contains $>50 \%$ inertite particles. The rest of the assemblage is dominated by well-preserved phytoclasts and contains small amounts of poorly preserved phytoclasts and well-preserved scleratoclasts. Facies 2 occurs within the Shikoku Basin hemipelagites $(600-1300 \mathrm{~m}$ below seafloor; sedimentation rate $<150 \mathrm{~m} / \mathrm{m} . \mathrm{y}$.) and contains over two-thirds inertite particles. The rest of the assemblage is dominated by poorly preserved phytoclasts. Miospores and marine phytoplankton compose only a small percentage of both palynofacies. Degraded organic matter is most noticeable in Facies 2, whereas its presence in Facies 1 is overshadowed by the high influx of well-preserved primary organic matter. Most of the degraded organic matter and inertite is interpreted to be reworked. Some of the degraded organic matter may be primary, and may have experienced more biodegradation and thermal alteration in Facies 2 than in Facies 1.

TAI values indicate an immature stage of organic maturation $(<2)$ down to about $900 \mathrm{mbsf}$. Below this, samples show an increase with depth to a mature stage, reaching peak levels of about $3^{-}$just above basement. Samples from within the thrust fault and décollement zones do not show levels of maturity significantly greater than those of surrounding samples, leaving uncertain whether hot fluids have migrated along these fault boundaries in the past.
\end{abstract}

\section{INTRODUCTION}

The Nankai Trough accretionary prism is formed from the subduction of the Philippine Sea Plate beneath the southern margin of Japan (Fig. 1). ODP Site 808 drilled completely through the Nankai prism, penetrating the frontal thrust fault, décollement, and into basement. The primary objectives of drilling were to study the influence of pore fluids and the hydrogeology of the prism on the mechanical state, physical properties, fabrics, and structural styles of the accreted sediments.

The sediment sequence can be divided into two primary units (Shipboard Scientific Party, 1991): the trench- wedge turbidites (0$600 \mathrm{~m}$ below seafloor [mbsf]), which were deposited at an extremely high sedimentation rate ( $>1 \mathrm{~km} / \mathrm{m} . \mathrm{y}$.) and the Shikoku Basin hemipelagites (600-1300 mbsf), which were deposited at a much slower sedimentation rate $(<150 \mathrm{~m} / \mathrm{m}$.y.). Site 808 intersects the frontal thrust fault of the accretionary prism at between $357-395$ mbsf. The stratigraphic throw of the fault is about $145 \mathrm{~m}$, and seismic imaging shows the fault intersecting the décollement at depth (Taira, Hill, Firth, et al., 1991). One objective of Leg 131 was to determine whether this fault has acted as a conduit for fluid flow as the prism dewaters during accretion. The décollement was also intersected at Site 808, between 945-964 mbsf, in the middle of the hemipelagite sequence. This is also a possible conduit of fluid flow in the prism.

Analysis of thermal structure and heat flow has been used as a tool to determine the nature of fluid flow within the Barbados accretionary prism (Fisher and Hounslow, 1990). Even though a detailed data set of thermal conductivity values was compiled for the Nankai prism, actual downhole temperature measurements at Site 808 were restricted to the upper $350 \mathrm{~m}$ using the WSTP tool, and the upper $750 \mathrm{~m}$ using the temperature log (Shipboard Scientific Party, 1991). There-

'Hill, I.A., Taira, A., Firth, J.V., et al., 1993. Proc. ODP, Sci. Results, 131: College Station, TX (Ocean Drilling Program).

${ }^{2}$ Ocean Drilling Program, Texas A\&M University, 1000 Discovery Drive, College Station, TX 77845-9547, U.S.A fore, the heat flow and temperature regime for the lower half of Hole $808 \mathrm{C}$ was based largely on extrapolation of data from the upper half. Another tool used for determining the temperature history of sediments is the color analysis of palynomorphs (Staplin, 1969). This technique was used to determine the levels of organic maturation in samples through the entire sediment section at Site 808 .

Palynofacies analysis of samples from Site 808 was undertaken to determine the origin, depositional environment, and diagenetic history of organic matter in the accreted sediments, whereas thermal maturation analysis was undertaken to determine the thermal structure and history of the prism and its relationship to fluid flow.

\section{METHODS}

Forty-one samples were taken from Holes $808 \mathrm{~A}, \mathrm{~B}$, and C, adjacent to samples taken for organic geochemistry analyses (Berner and Faber, this volume). Before processing, each sample was dried and weighed (Table 1). Two tablets of Lycopodium spores $(11,300 \pm 400$ spores /tablet) were added to each sample to calculate the quantitative abundances of the various organic constituents in the sediments. Each sample then underwent maceration with $\mathrm{HCl}$ and $\mathrm{HF}$. Three random strewn kerogen slides were made for each sample. All slides were made using ETOH as a dispersant and PVA as a mounting medium.

The kerogen slides were examined under a Zeiss Photomicroscope at $250 \times$ and $400 \times$ magnification. Classification of organic matter is based on the Hartax system (Hart, 1986), which recognizes phytoclasts (terrestrial plant fragments such as cuticle and tracheids), miospores, marine phytoplankton, scleratoclasts (fungal spores and hyphae), inertite, amorphous material, and resin. This system also subdivides some of these categories based on degree of preservation. I modified this system by combining different types of amorphous material into just one category; also my determination of inertite, using plain transmitted light, undoubtedly includes some highly reflective vitrinite as well as inertinite of coal maceral terminology. Table 2 shows the modified Hartax classification system used for this study, along with the equivalent coal maceral terminology. One 


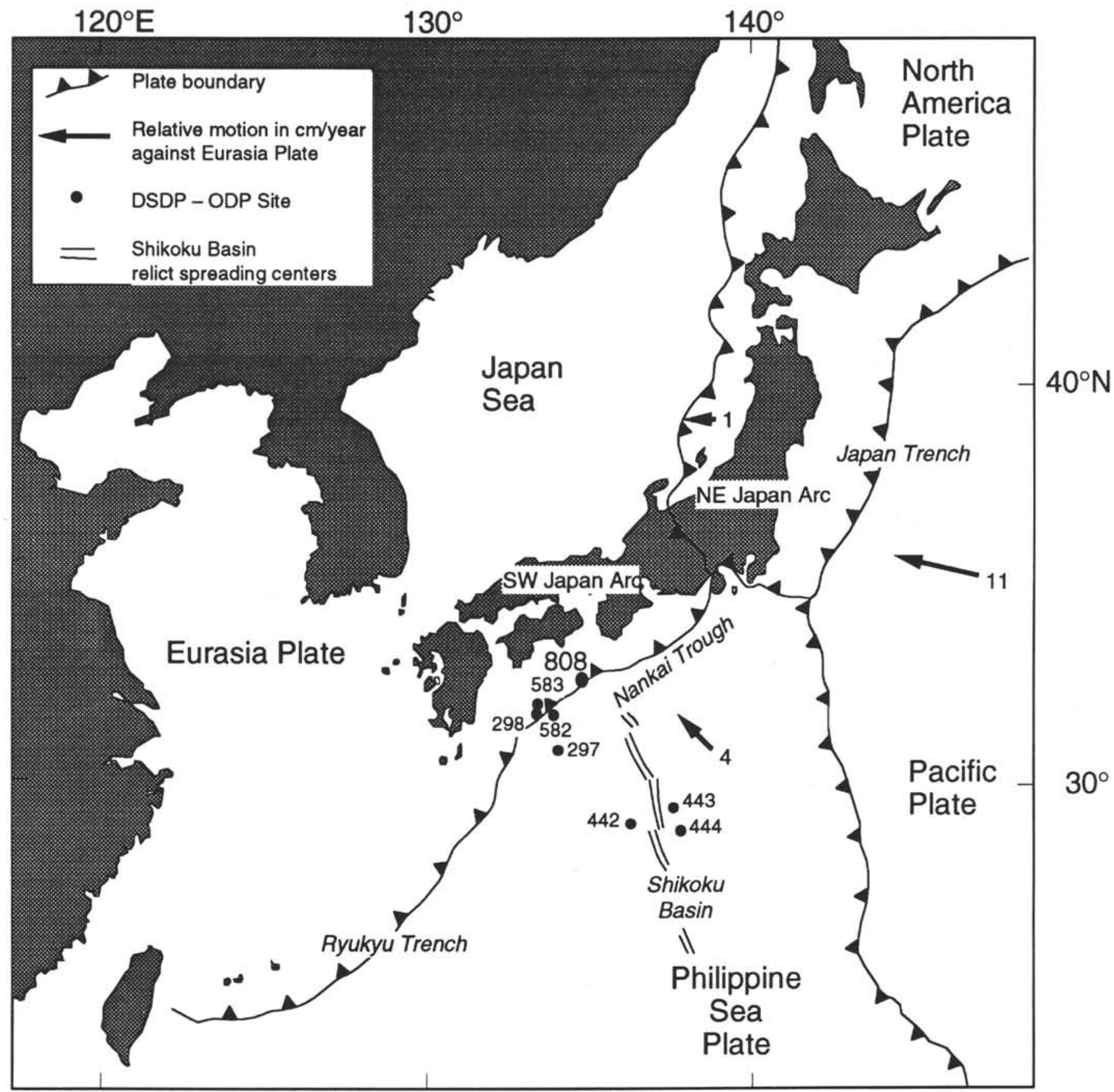

Figure 1. Tectonic map of the Philippine Sea showing location of ODP Site 808 and DSDP Sites 297, 298, 582, and 583 in the Nankai Trough, and Sites 442,443 , and 444 in the Shikoku Basin.

hundred fifty organic particles per slide, and two slides per sample were counted, for a total of 300 particles per sample (Table 3) Because of the inordinate amount of small inertite particles in all samples, only particles $>5 \mu \mathrm{m}$ in size were counted. This ensured that representative counts of other particles were made within the total count of 300 . This also means that values of inertite in particles per gram and \% composition are underestimated in all samples. The size cutoff of $5 \mu \mathrm{m}$ is smaller than the $10 \mu \mathrm{m}$ cutoff used by Mukhopadhyay et al. (1985) for nearby DSDP Sites 582 and 583. This may explain the difference between the proportions of inertite reported in this study and that reported by Mukhopadhyay et al. (1985).
Calculations of the absolute abundances of different organic constituents, in number (\#) of particles per gram of sediment, were made by first weighing the dried samples and adding an aliquot of Lycopodium spores $(22,600 \pm 800 /$ sample $)$. The number of Lycopodium spores in a count of 1000 particles per sample was recorded. Conversion of number of particles per count of 300 to number of particles per gram of sediment was made using the following formula:

(\# of particles/300 particles) · [300 particles/(0.3 - \# Lycopodium) ]

(\# Lycopodium/sample) $\cdot($ sample/g) = \# of particles/g. 
Table 1. List of samples, sample depths, sample weights, age, and calcareous nannofossil zone assignments.

\begin{tabular}{|c|c|c|c|c|c|}
\hline $\begin{array}{l}\text { Sample } \\
\text { number }\end{array}$ & $\begin{array}{l}\text { Core, section, } \\
\text { interval }(\mathrm{cm})\end{array}$ & $\begin{array}{l}\text { Depth } \\
\text { (mbsf) }\end{array}$ & $\begin{array}{l}\text { Weight } \\
\text { (g) }\end{array}$ & Age & $\begin{array}{c}\text { Nannofossil } \\
\text { Zone }\end{array}$ \\
\hline & Hole $808 \mathrm{~A}$ - & & & & \\
\hline 1 & $2 \mathrm{H}-6,5-7$ & 13.8 & 18.2 & Pleistocene & $\mathrm{NN} 20$ \\
\hline \multirow[t]{2}{*}{2} & $9 \mathrm{H}-4,3-5$ & 72.8 & 21.8 & Pleistocene & $\mathrm{NN} 20$ \\
\hline & Hole 808B- & & & & \\
\hline 3 & $2 X-1,50-52$ & 121.1 & 14.3 & Pleistocene & NN20 \\
\hline 4 & $7 X-4,29-31$ & 173.6 & 18.5 & Pleistocene & $\mathrm{NN} 20$ \\
\hline 5 & $17 \mathrm{X}-1,59-61$ & 264.0 & 24.6 & Pleistocene & NN20 \\
\hline \multirow[t]{2}{*}{6} & $25 X-3,35-37$ & 339.4 & 16.2 & Pleistocene & NN20 \\
\hline & Fole $808 \mathrm{C}$ - & & & & \\
\hline 7 & IR-1, 116-118 & 299.7 & 13.5 & Pleistocene & $\mathrm{NN} 20$ \\
\hline 8 & $7 \mathrm{R}-1,37-39$ & 356.6 & 18.2 & Pleistocene & NN20 \\
\hline 9 & $8 \mathrm{R}-1,23-25$ & 366.1 & 17.4 & Pleistocene & NN20 \\
\hline 10 & $9 \mathrm{R}-1,12-14$ & 375.7 & 20.8 & Pleistocene & NN20 \\
\hline 11 & $10 \mathrm{R}-2,4-7$ & 386.7 & 34.7 & Pleistocene & NN20 \\
\hline 12 & $11 \mathrm{R}-2,42-44$ & 396.7 & 12.9 & Pleistocene & $\mathrm{NN} 20$ \\
\hline 13 & $12 \mathrm{R}-3,8-10$ & 407.7 & 4.2 & Pleistocene & NN20 \\
\hline 14 & $15 \mathrm{R}-1,28-30$ & 434.0 & 27.0 & Pleistocene & NN20 \\
\hline 15 & $17 \mathrm{R}-2,42-44$ & 454.6 & 23.0 & Pleistocene & NN20 \\
\hline 16 & $22 \mathrm{R}-1,32-35$ & 501.3 & 23.9 & Pleistocene & NN20 \\
\hline 17 & 23R-2, 91-92 & 513.1 & 4.9 & Pleistocene & NN20 \\
\hline 18 & $23 \mathrm{R}-3,105-106$ & 514.7 & 8.1 & Pleistocene & $\mathrm{NN} 20$ \\
\hline 19 & $28 \mathrm{R}-2,78-80$ & 561.2 & 27.6 & Pleistocene & NN20 \\
\hline 20 & $32 R-3,15-17$ & 600.5 & 8.3 & Pleistocene & NN19 \\
\hline 21 & $37 \mathrm{R}-1,88-91$ & 646.4 & 44.6 & Pleistocene & NN19 \\
\hline 22 & $42 R-4,54-57$ & 698.5 & 37.9 & Pleistocene & NN19 \\
\hline 23 & $47 R-4,70-72$ & 746.6 & 33.1 & Pleistocene & NN19 \\
\hline 24 & $50 \mathrm{R}-1,15-17$ & 780.3 & 24.8 & Pliocene & NN19 \\
\hline 25 & $52 R-5,28-30$ & 796.1 & 20.1 & Pliocene & NN18 \\
\hline 26 & $57 R-4,70-72$ & 843.3 & 12.0 & Pliocene & NN16-NN17 \\
\hline 27 & 58R-3, 41-42 & 850.8 & 4.0 & Pliocene & NN16-NN17 \\
\hline 28 & $61 R-4,57-58$ & 881.7 & 6.0 & Pliocene & NN14-NN15 \\
\hline 29 & $67 R-1,61-63$ & 935.1 & 21.0 & Pliocene & $\mathrm{NN} 12$ \\
\hline 30 & $69 R-3,52-54$ & 957.3 & 28.3 & Pliocene & $\mathrm{NN} 12$ \\
\hline 31 & $70 \mathrm{R}-1,117-119$ & 964.6 & 20.8 & Miocene & NN11 \\
\hline 32 & $70 R-2,62-65$ & 965.5 & 25.6 & Miocene & NN11 \\
\hline 33 & $73 \mathrm{R}-6,51-53$ & 1000.8 & 14.6 & Miocene & NN11 \\
\hline 34 & $78 \mathrm{R}-5,42-45$ & 1045.5 & 15.8 & Miocene & NN8-NN10 \\
\hline 35 & $83 R-2,114-117$ & 1088.5 & 22.5 & Miocene & NN8-NN10 \\
\hline 36 & $87 \mathrm{R}-1,23-27$ & 1117.8 & 21.0 & Miocene & NN7 \\
\hline 37 & $88 \mathrm{R}-1,101-103$ & 1127.9 & 14.8 & Miocene & NN7 \\
\hline 38 & $92 \mathrm{R}-1,42-45$ & 1166.0 & 20.9 & Miocene & NN7 \\
\hline 39 & $96 \mathrm{R}-1,103-104$ & 1205.3 & 10.6 & Miocene & NN6 \\
\hline 40 & $98 R-1,67-69$ & 1224.4 & 21.5 & Miocene & NN5 \\
\hline 41 & $103 R-1,90-92$ & 1271.8 & 23.2 & Miocene & NN5 \\
\hline
\end{tabular}

Note: Zonation scheme is from Martini (1971), zonal assignments are from Olafsson (this volume).

Tabulation of spores and pollen at Site 808 indicates that few taxa occur throughout the sequence from Miocene to Holocene age. Also, abundance of miospores is low in all samples. Because of the scarcity of material and the few long-ranging taxa, I did not base thermal maturation estimates on a single taxon. Instead, I recorded the thermal alteration index (TAI) values of the first 50 miospores encountered in straight transects across the slides ( 25 /slide, 2 slides/sample) as an indication of the overall maturation level of each sample (Table 3). TAI values were determined by comparison with the pollen/spore color chart of Pearson (1984). Mean TAI values of 50 miospores per sample were calculated by using numerical values assigned to each TAI color-number, as follows: $1=1 ; 1^{+}=1.33 ; 2^{-}=1.67 ; 2=2 ; 2^{+}=$ $2.33 ; 3^{-}=2.67 ; 3=3 ; 3^{+}=3.33 ; 4^{-}=3.67 ; 4=4 ; 5=5$. Although color change is not a linear scale, the impartation of a linear numerical scale and calculation of mean values is useful in presenting a picture of the maturation level of the sample as a whole. However, I also present histograms of TAI values per sample, showing the complete
Table 2. Comparison of terminology between the Hartax classification system and coal maceral terminology.

\begin{tabular}{|c|c|}
\hline Modified Hartax classification & Coal maceral terminology \\
\hline Well-preserved phytoclast & exinite, cutinite, huminite \\
\hline Poorly preserved phytoclast & exinite, liptodetrinite, huminite, vitrinite \\
\hline Amorphous organic matter & exinite, liptodetrinite, huminite, vitrinite, alginite \\
\hline Resin & exinite, resinite \\
\hline Inertite & inertinite, inertodetrinite, vitrinite, micrinite \\
\hline Miospore & exinite, sporinite \\
\hline Marine phytoplankton & exinite, alginite \\
\hline Well-preserved scleratoclast & inertinite, sclerotinite, \\
\hline Poorly preserved scleratoclast & inertinite, sclerotinite, liptodetrinite \\
\hline Microforaminifera (zooclasts) & faunal relics \\
\hline
\end{tabular}

Note: Hartax classification (Hart, 1986) is modified herein, and coal maceral terminology (as defined in Stach et al., 1982) is as used in Rullkötter et al. (1980) and Mukhopadhyay et al. (1985).

distribution of miospore colors, which are the primary basis for interpreting the thermal maturation of the samples.

\section{PALYNOFACIES ANALYSIS}

\section{Qualitative Analysis}

The results of the tabulation of organic constituents is shown in Table 3, Figures 2 and 3, and Plate 1. Total organic carbon (TOC) makes up less than $1 \%$ of the sediments in the Nankai Trough (Shipboard Scientific Party, 1991), and shows a progressive decline with depth (Fig. 2). The trench turbidites contain mostly $>0.5 \%$ TOC, whereas the Shikoku Basin hemipelagites contain mostly $<0.5 \%$ TOC. This is consistent with the results from Sites 582 and 583 in the Nankai Trough (Mukhopadhyay et al., 1985). Two distinct palynofacies are recognized that correspond with the trench-wedge turbidite lithofacies and the Shikoku Basin hemipelagite lithofacies: Facies 1 occurs from 0 to 600 mbsf, and Facies 2 occurs from 600 to 1300 mbsf. Inertite is the most abundant constituent of both facies, making up over $50 \%$ of Facies 1 and over $67 \%$ of Facies 2 . Most inertite particles counted (exclusive of those not counted, $<5 \mu \mathrm{m}$ ) are small, between 5 and $20 \mu \mathrm{m}$.

Facies 1, exclusive of inertite, consists primarily of well-preserved phytoclasts, and secondarily of poorly preserved phytoclasts and well-preserved scleratoclasts (Plate 2, Figs. 1, 2, 9). The phytoclasts are mostly large $(>30 \mu \mathrm{m})$, and may comprise most of the organic matter by volume, if not by number. Miospores and marine phytoplankton are rare. This facies closely resembles the vascular tissue facies of Habib and Miller (1989), in that it is characterized by a large amount of well-preserved terrestrial plant fragments and ubiquitous inertite. This facies also resembles the exinitic facies of Habib (1979), but differs in the large amount of inertite particles present, the large amount of phytoclasts, and the relatively small amount of miospores.

Facies 2, exclusive of inertite, consists primarily of poorly preserved phytoclasts, with only minor amounts of all other constituents. Well-preserved phytoclasts diminish drastically in abundance beginning at 600 mbsf, which corresponds to the base of the turbidites at Site 808 (Shipboard Scientific Party, 1991). Many of the poorly preserved phytoclasts are small and dark brown in color, are difficult to identify as plant fragments, and would have been classified as inertite if they were brownish black to black in color. Marine phytoplankton are still rare, but slightly more abundant than in Facies 1 . Below about $1100 \mathrm{mbsf}$ they consist of rare, well-preserved dinoflagellates (Plate 2, Fig. 8) and sparse disk-shaped forms with central capsules, reminiscent of the chlorophyte-algae Pterospermella (Plate 4, Figs. 10-11). This facies closely resembles the micrinitic facies of Habib (1979), which also contains an extreme abundance of inertite, a smaller amount of poorly preserved phytoclasts, and small amounts of palynomorphs, with greater numbers of marine phytoplankton than miospores. 
Table 3. List of components of organic particles in samples from Site 808.

\begin{tabular}{|c|c|c|c|c|c|c|c|c|c|c|c|c|c|c|}
\hline $\begin{array}{l}\text { Sample } \\
\text { Hole-Core-Section, } \\
\text { interval }(\mathrm{cm})\end{array}$ & $\begin{array}{l}\text { Depth } \\
\text { (mbsf) }\end{array}$ & Wpph & Ppph & Aom & Wpmio & Ppmio & Inert & Resin & Wpsc & Ppsc & Mphy & Micf & $\begin{array}{c}\text { Mean } \\
\text { TAI }\end{array}$ & $\begin{array}{c}\text { \# Lycopodium } \\
\text { per } 1000\end{array}$ \\
\hline $808 \mathrm{~A}-2 \mathrm{H}-6,5-7$ & 13.8 & 113 & 7 & 2 & 5 & 1 & 142 & 0 & 25 & 5 & 0 & 0 & 1.71 & 3 \\
\hline $808 \mathrm{~A}-9 \mathrm{H}-4,3-5$ & 72.8 & 87 & 10 & 3 & 2 & 1 & 176 & 0 & 17 & 4 & 0 & 0 & 1.87 & 1 \\
\hline $808 \mathrm{~B}-2 \mathrm{X}-1,50-52$ & 121.1 & 176 & 19 & 2 & 1 & 0 & 87 & 0 & 14 & 1 & 0 & 0 & 2.02 & 2 \\
\hline $808 \mathrm{~B}-7 \mathrm{X}-4,29-31$ & 173.6 & 15 & 25 & 11 & 0 & 0 & 244 & 0 & 3 & 2 & 0 & 0 & 1.73 & 6 \\
\hline $808 B-17 X-1,59-61$ & 264.0 & 89 & 23 & 10 & 5 & 0 & 146 & 0 & 18 & 9 & 0 & 0 & 1.89 & 4 \\
\hline $808 \mathrm{~B}-25 \mathrm{X}-3,35-37$ & 339.4 & 40 & 87 & 9 & 0 & 0 & 148 & 0 & 15 & 1 & 0 & 0 & 1.87 & 2 \\
\hline $808 C-1 R-1,116-118$ & 299.7 & 99 & 37 & 2 & 2 & 1 & 148 & 0 & 9 & 2 & 0 & 0 & 1.86 & 4 \\
\hline $808 \mathrm{C}-7 \mathrm{R}-1,37-39$ & 356.6 & 79 & 33 & 3 & 7 & 1 & 156 & 0 & 18 & 3 & 0 & 0 & 1.88 & 2 \\
\hline $808 \mathrm{C}-8 \mathrm{R}-1,23-25$ & 366.1 & 59 & 47 & 7 & 8 & 1 & 163 & 0 & 12 & 2 & 0 & 0 & 1.89 & 4 \\
\hline $808 \mathrm{C}-9 \mathrm{R}-1,12-14$ & 375.7 & 101 & 63 & 6 & 7 & 0 & 102 & 0 & 20 & 1 & 0 & 0 & 1.92 & 4 \\
\hline $808 \mathrm{C}-10 \mathrm{R}-2,4-7$ & 386.7 & 100 & 21 & 0 & 6 & 2 & 164 & 0 & 7 & 0 & 0 & 0 & 1.94 & 3 \\
\hline $808 \mathrm{C}-11 \mathrm{R}-2,42-44$ & 396.7 & 127 & 34 & 2 & 3 & 1 & 115 & 1 & 15 & 2 & 0 & 0 & 1.91 & 4 \\
\hline $808 \mathrm{C}-12 \mathrm{R}-3,8-10$ & 407.7 & 94 & 49 & 8 & 6 & 0 & 127 & 1 & 12 & 3 & 0 & 0 & 1.83 & 10 \\
\hline $808 \mathrm{C}-15 \mathrm{R}-1,28-30$ & 434.0 & 72 & 25 & 2 & 3 & 2 & 178 & 0 & 18 & 0 & 0 & 0 & 1.97 & 2 \\
\hline $808 \mathrm{C}-17 \mathrm{R}-2,42-44$ & 454.6 & 98 & 49 & 4 & 3 & 0 & 133 & 0 & 12 & 1 & 0 & 0 & 2.01 & 2 \\
\hline $808 \mathrm{C}-22 \mathrm{R}-1,32-35$ & 501.3 & 50 & 56 & 3 & 4 & 2 & 172 & 0 & 13 & 0 & 0 & 0 & 1.83 & 2 \\
\hline $808 \mathrm{C}-23 \mathrm{R}-2,91-92$ & 513.1 & 21 & 63 & 14 & 0 & 0 & 185 & 0 & 9 & 8 & 0 & 0 & 1.84 & 8 \\
\hline $808 \mathrm{C}-23 \mathrm{R}-3,105-106$ & 514.7 & 118 & 64 & 3 & 2 & 0 & 103 & 0 & 10 & 0 & 0 & 0 & 1.90 & 6 \\
\hline $808 \mathrm{C}-28 \mathrm{R}-2,78-80$ & 561.2 & 65 & 84 & 2 & 6 & 0 & 136 & 0 & 5 & 2 & 0 & 0 & 2.05 & 1 \\
\hline $808 \mathrm{C}-32 \mathrm{R}-3,15-17$ & 600.5 & 17 & 30 & 9 & 3 & 2 & 235 & 0 & 3 & 1 & 0 & 0 & 1.64 & 13 \\
\hline $808 \mathrm{C}-37 \mathrm{R}-1,88-91$ & 646.4 & 17 & 46 & 4 & 6 & 1 & 221 & 1 & 3 & 1 & 0 & 0 & 1.96 & 2 \\
\hline $808 C-42 R-4,54-57$ & 698.5 & 15 & 74 & 5 & 1 & 1 & 198 & 0 & 4 & 2 & 0 & 0 & 2.03 & 2 \\
\hline $808 \mathrm{C}-47 \mathrm{R}-4,70-72$ & 746.6 & 13 & 46 & 18 & 0 & 0 & 221 & 0 & 2 & 0 & 0 & 0 & 1.96 & 1 \\
\hline $808 \mathrm{C}-50 \mathrm{R}-1,15-17$ & 780.3 & 19 & 53 & 9 & 0 & 2 & 214 & 0 & 3 & 0 & 0 & 0 & 1.77 & 2 \\
\hline $808 \mathrm{C}-52 \mathrm{R}-5,28-30$ & 796.1 & 13 & 59 & 6 & 7 & 0 & 211 & 0 & 1 & 3 & 0 & 0 & 1.66 & 3 \\
\hline $808 \mathrm{C}-57 \mathrm{R}-4,70-72$ & 843.3 & 6 & 43 & 11 & 2 & 0 & 230 & 0 & 4 & 3 & 0 & 1 & 1.86 & 11 \\
\hline $808 \mathrm{C}-58 \mathrm{R}-3,41-42$ & 850.8 & 14 & 49 & 23 & 4 & 0 & 193 & 0 & 12 & 5 & 0 & 0 & 1.91 & 22 \\
\hline $808 \mathrm{C}-61 \mathrm{R}-4,57-58$ & 881.7 & 19 & 56 & 18 & 1 & 1 & 195 & 0 & 3 & 7 & 0 & 0 & 1.76 & 20 \\
\hline $808 \mathrm{C}-67 \mathrm{R}-1,61-63$ & 935.1 & 8 & 41 & 3 & 2 & 0 & 240 & 0 & 3 & 3 & 0 & 0 & 2.05 & 5 \\
\hline $808 \mathrm{C}-69 \mathrm{R}-3,52-54$ & 957.3 & 1 & 35 & 0 & 0 & 0 & 257 & 0 & 5 & 2 & 0 & 0 & 2.05 & 4 \\
\hline 808C-70R-1, 117-119 & 964.6 & 2 & 52 & 2 & I & 0 & 237 & 0 & 3 & 3 & 0 & 0 & 2.22 & 9 \\
\hline $808 \mathrm{C}-70 \mathrm{R}-2,62-65$ & 965.5 & 6 & 39 & 3 & 1 & 1 & 244 & 0 & 2 & 3 & 1 & 0 & 2.25 & 7 \\
\hline $808 \mathrm{C}-73 \mathrm{R}-6,51-53$ & 1000.8 & 2 & 56 & 13 & 2 & 0 & 226 & 0 & 0 & 1 & 0 & 0 & 2.31 & 6 \\
\hline $808 C-78 R-5,42-45$ & 1045.5 & 4 & 56 & 10 & 3 & 2 & 221 & 0 & 3 & 1 & 0 & 0 & 2.50 & 11 \\
\hline $808 C-83 R-2,114-117$ & 1088.5 & 2 & 67 & 15 & 0 & 0 & 210 & 0 & 5 & 1 & 0 & 0 & 2.49 & 3 \\
\hline $808 \mathrm{C}-87 \mathrm{R}-1,23-27$ & 1117.8 & 6 & 67 & 17 & 2 & 0 & 200 & 0 & 6 & 1 & 1 & 0 & 2.54 & 2 \\
\hline 808C-88R-1, 101-103 & 1127.9 & 2 & 60 & 10 & 3 & 0 & 216 & 0 & 4 & 5 & 0 & 0 & 2.50 & 5 \\
\hline $808 \mathrm{C}-92 \mathrm{R}-1,42-45$ & 1166.0 & 1 & 68 & 20 & 7 & 1 & 197 & 0 & 3 & 3 & 0 & 0 & 2.54 & 4 \\
\hline 808C-96R-1, 103-104 & 1205.3 & 0 & 80 & 22 & 2 & 2 & 184 & 0 & 5 & 4 & 1 & 0 & 2.50 & 5 \\
\hline $808 \mathrm{C}-98 \mathrm{R}-1,67-69$ & 1224.4 & 1 & 44 & 19 & 4 & 0 & 225 & 0 & 2 & 5 & 0 & 0 & 2.82 & 6 \\
\hline $808 \mathrm{C}-103 \mathrm{R}-1,90-92$ & 1271.8 & 1 & 34 & 6 & 0 & 0 & 255 & 0 & 1 & 2 & 1 & 0 & 2.82 & 6 \\
\hline
\end{tabular}

Note: $\mathrm{Wpph}=$ well-preserved phytoclasts; $\mathrm{Ppph}=$ poorly preserved phytoclasts; $\mathrm{Aom}=$ amorphous organic matter; $\mathrm{Wpmio}=$ well-preserved miospores; $\mathrm{Ppmio}=$ poorly preserved miospores; Inert = inertite; Resin = resin; $\mathrm{Wpsc}=$ well-preserved scleratoclasts; Ppsc = poorly preserved scleratoclasts; Mphy = marine phytoplankton; Micf = microforaminifers. $\mathrm{TAI}=$ thermal alteration index.

\section{Quantitative Analysis}

Absolute abundances of organic constituents show different trends than do the relative abundances (Fig. 3). Well-preserved phytoclasts and scleratoclasts show large absolute abundances in the trench turbidites and very low abundances in the hemipelagites. Inertite and poorly preserved phytoclasts and scleratoclasts show similar absolute abundances between turbidites and hemipelagites. Miospores show slightly larger absolute abundances in the turbidites, whereas amorphous organic matter shows slightly larger abundances in the hemipelagites. Marine phytoplankton show much larger absolute abundances in the hemipelagites; however, this trend may be misleading because they were likely flooded out by terrestrial plant fragments in the turbidites and thus were not recorded in counts of 300 .

Accumulation rates of selected organic constituents were calculated by multiplying their absolute abundances by the corresponding sediment mass accumulation rates (Shipboard Scientific Party, 1991) for the intervals containing each sample (Fig. 4). In each case, the pattern of accumulation rates for each constituent reflects the large increase in the overall sediment accumulation rate with the onset of trench turbidite sedimentation. The combination of large increases in absolute abundance and accumulation rates of well-preserved phytoclasts and scleratoclasts resulted in large increases in their relative abundance in the turbidites. On the other hand, the combination of large increases in accumulation rates of inertite and degraded and amorphous organic matter, with increases in absolute abundances of these constituents (owing to a corresponding increase in the overall sediment accumulation rates) resulted in no significant increases in their relative abundances in the turbidites.

The closer proximity of the trench turbidite facies to a terrestrial source of primary organic matter, and the rapid burial of organic matter that retarded its oxidation and degradation, are the primary reasons for the difference in organic matter content between Facies 1 and Facies 2. The greater influx of well-preserved organic matter contributed to the overall increase in TOC from the hemipelagites to the turbidites.

\section{Discussion}

Mukhopadhyay et al. (1985) analyzed the organic matter from DSDP Sites 582 and 583 in the Nankai Trough and found that most of it is also terrestrially derived. They determined three sources of organic matter in the trench turbidites: marine algal matter (alginite) from a shallow marine environment, well-preserved phytoclasts from a nearby coastal swamp environment, and reworked inertite and degraded and oxidized phytoclasts from a distal land source. Of these the latter two organic matter types are recognized in sediments from Site 808 . The marine thalloid algal matter recognized at Site 583 


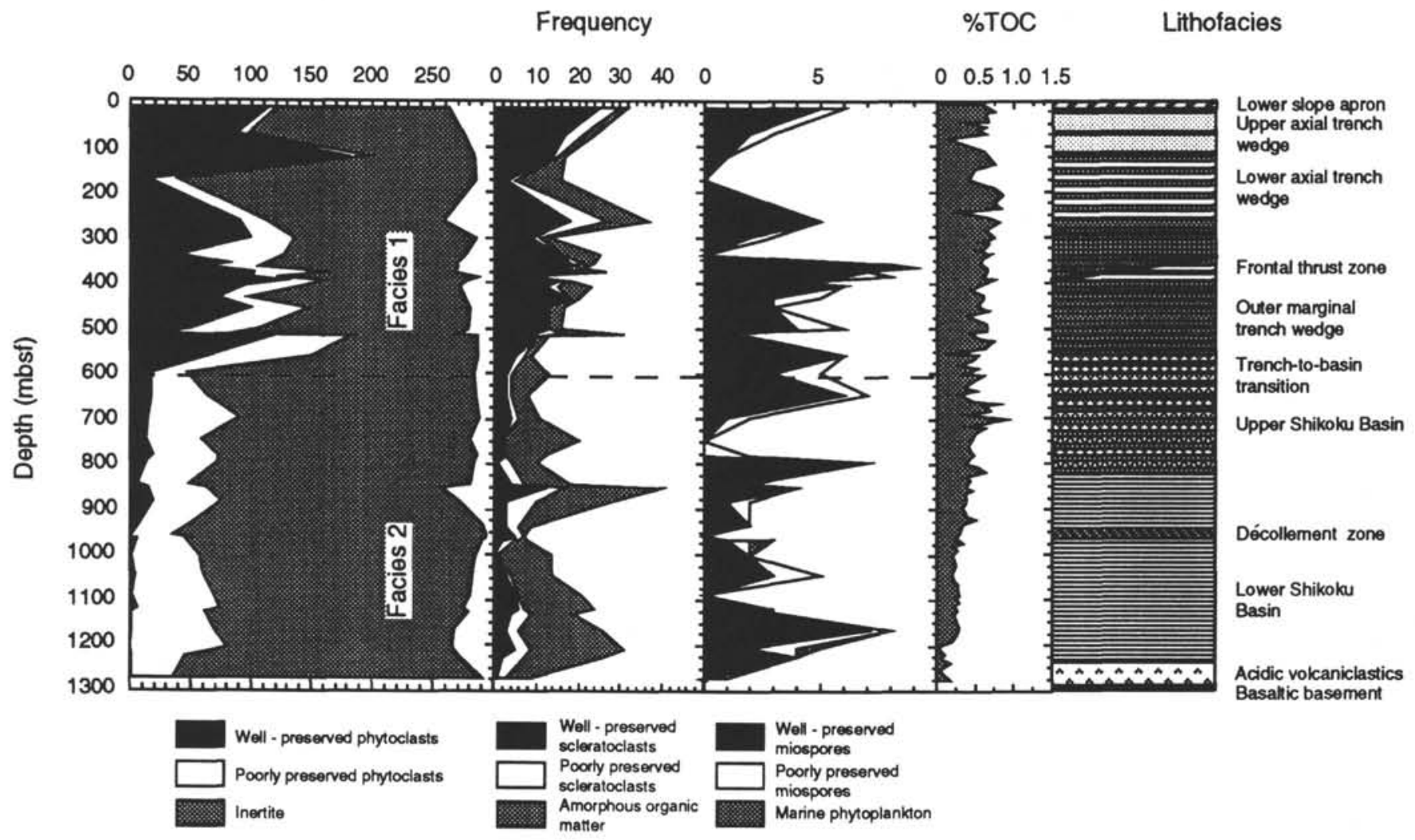

Figure 2. Frequency of organic constituents (out of a count of 300 particles/sample), percent total organic carbon (TOC), and lithostratigraphy of Site 808 . Lithostratigraphy and TOC values are from Shipboard Scientific Party (1991).

occurs in high amounts in one sample from a turbidite bed. This type of marine algal material was not observed at Site 808 .

Rullkötter et al. (1980) determined low TOC values $(0.4 \%$ down to $<0.1 \%$ ) and a dominance of terrestrial plant material in northern Shikoku Basin sediments (DSDP Sites 442, 443, and 444). The terrestrial organics are composed dominantly of inertite and secondarily of poorly preserved-to-amorphous phytoclasts. Rullkötter et al. (1980) interpreted most of the terrestrial organics in the Shikoku Basin to be reworked from older sediments rather than primary organic matter. Samples of Plio-Pleistocene hemipelagites from the Nankai Trough (Site 582) also contain large proportions of poorly preserved-to-amorphous phytoclasts and inertite (Mukhopadhyay et al., 1985). Based on these other studies, the more poorly preserved phytoclasts occurring throughout the section at Site 808 are probably largely composed of reworked material and secondarily composed of degraded primary organic material.

The large amount of reworked organic matter in both Facies 1 and Facies 2 further suggests that miospores may also be largely reworked. This complicates the interpretation of thermal maturation of the sediments based on miospore TAI values.

\section{THERMAL MATURATION ANALYSIS}

Observations of miospores in Nankai sediments show a wide range of TAI values in individual samples. Even individual taxa show a range of values from 1 to $2^{+}$in individual samples. The range of values of 50 miospores/sample, however, decreases with depth and shows more closely constrained, higher values in Facies 2 than in Facies 1 (Figs. 5 and 6).

The TAI values within the upper $850-900 \mathrm{~m}$ of sediments, corresponding to the trench-wedge turbidites and upper Shikoku Basin hemipelagites, show wide ranges within samples and no consistent trend with depth (Figs. 5 and 6). The mean TAI fluctuates between
1.6 and 2.0 , corresponding to immature sediments with vitrinite reflectance values of $<0.4 \%$. The fluctuations and wide range of TAI values are most likely because the miospore assemblage consists of a mix of both primary grains and reworked grains from older parts of the accretionary prism or from eroded sequences on land. In a few samples, extremely darkened forms were observed (TAI of $4^{-}$) in shallow sediments ( $<400 \mathrm{mbsf}$ ), which can be interpreted as reworked older specimens. Those that show TAI values of $2^{-}$to $2^{+}$, however, and are the same taxa as specimens with TAI values of 1 to $1^{+}$, are more difficult to recognize as being reworked.

Below 900 mbsf, the mean TAI values increase dramatically with depth, from about 2.05 to over 2.8. The two deepest samples appear to have significantly higher TAI values than those from between $1000-1200$ mbsf. These two samples occur within and immediately above the tuff units that overlie basaltic basement. Thermal conductivity measurements of Site 808 samples show conductivity values reaching over $2.0 \mathrm{~W} / \mathrm{m} \cdot \mathrm{K}$ in the tuff units and hemipelagites below 1200 mbsf (Shipboard Scientific Party, 1991). This, and the close proximity to basement, may have contributed to the significant darkening of the two deepest samples analyzed in this study. Mean TAI values below the décollement are all greater than 2.2 , and reflect a mature stage of organic maturation.

Histograms of TAI values (Fig. 6) in the trench turbidites and upper hemipelagites show some clear bimodal distributions (at 13.8, $121.1,396.7,501.3$, and $600.5 \mathrm{mbsf}$ ) as well as wide, even distributions that indicate a mix of reworked darker miospores with lighter, indigenous miospores. The lighter values are considered indicative of the thermal maturity of the sediments, down to the level of the décollement. From this depth down to $1300 \mathrm{mbsf}$, the histograms show unimodal distributions with narrower ranges of values. The mode of these histograms increases steadily from 2 (at $957.3 \mathrm{mbsf}$ ) to $3^{-}$(at $1271.8 \mathrm{mbsf}$ ). Light-colored miospores (TAI $=1$ to $2^{-}$) are still present at depth, although they become very sparse to absent 

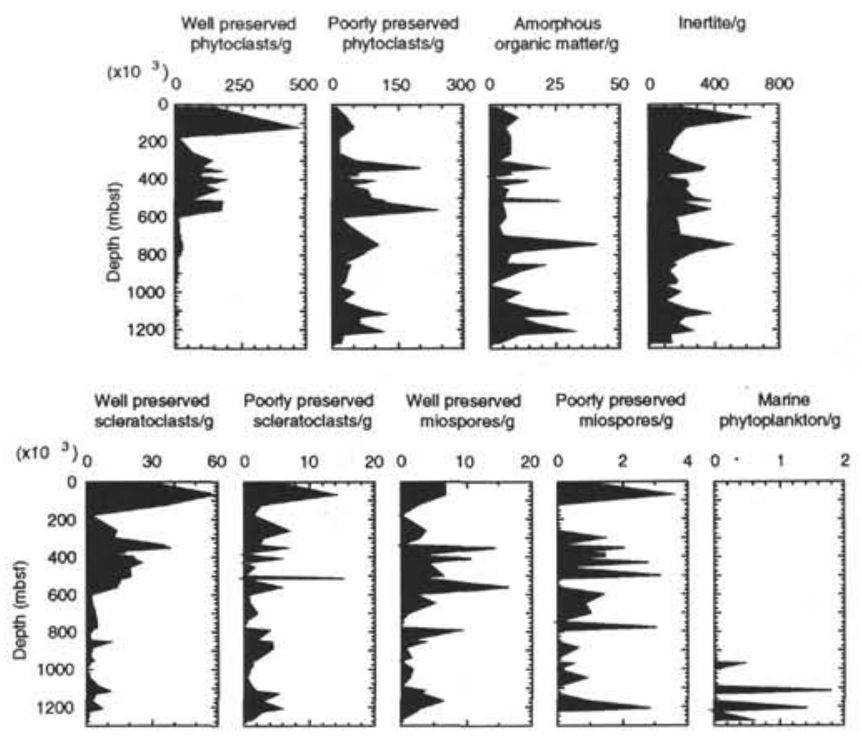

Figure 3. Absolute abundances (in particles/g) of organic constituents at Site 808 .

below the décollement and are primarily very thin-walled, subspheri$\mathrm{cal}$, monaperturate, or inaperturate forms. The presence of these specimens may be interpreted in several ways: (1) although recorded as miospores, they may also be algal cysts of unknown affinity that may not darken as readily as terrestrial miospores; (2) they may be contamination; (3) their color may be deceptive because the very thin, transparent walls appear lighter than their true color (e.g., Plate 4, Fig. 4); (4) they may be primary rather than reworked miospores that give a true indication of maturation of the deeper sediments (in this case, immature). I believe that interpretations 2 and 4 are not true in this case, because (1) the samples were carefully cleaned of their outer surfaces so as not to incorporate contaminated material into the maceration process (this does not completely prevent present-day airborne pollen from entering the samples, although such pollen was not observed in the processed slides), (2) organic geochemical analyses of Site 808 sediments (Berner and Faber, this volume) show a trend toward mature levels beginning below $850 \mathrm{mbsf}$, (3) the deepest sample analyzed, at $1271.8 \mathrm{mbsf}$, does not contain light-colored forms, indicating a true high level of maturity, and (4) dinoflagellate cysts (Impagidinium spp., which are recognized by Wrenn and Kokinos [1986] as outer neritic to oceanic taxa) show a darkening trend similar to the miospores (Table 4; Plate 3, Figs. 9-12). Therefore, I believe interpretations 1 and 3 are more applicable, and that the trend shown by mean TAI values accurately indicates a mature stage of organics below the décollement.

Calculated heat-flow curves for Site 808 predict a bottom-hole temperature of roughly $120^{\circ} \mathrm{C}$ (Fig. 5). To compare the TAI values of the basal samples to the predicted bottom-hole temperature, a rough calculation was made using the time-dependant method of Hood et al. (1975). A TAI value of 2.8 is equivalent to a vitrinite reflectance value of roughly $0.85 \%$ (Waples, 1980; Hood et al., 1975). This equates with a level of maturity (LOM) value of about 10 . Using an effective heating time of 0.5 m.y. (roughly equal to the age of onset of trench turbidite sedimentation and deep burial of the hemipelagites), this model estimates a maximum heating temperature of 180 $190^{\circ} \mathrm{C}$. However, if the modal TAI value (2.67) for the basal samples is used rather than the mean TAI value, the LOM is then equal to 9 and the estimated maximum temperature is about $150^{\circ} \mathrm{C}$. In contrast, the correlation of organic maturity indicators by Heroux et al. (1979) places the basal samples in the middle of the mature stage of maturation, at a maximum temperature of roughly $100^{\circ} \mathrm{C}$. Without detailed

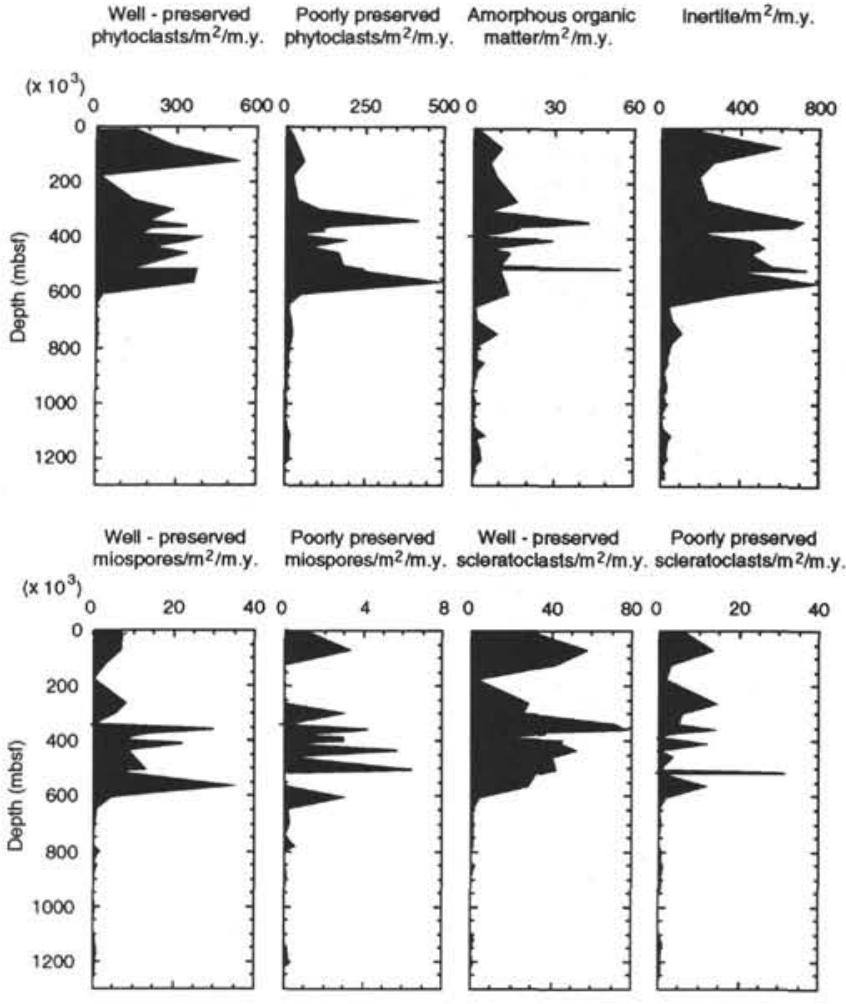

Figure 4. Accumulation rates (in particles $/ \mathrm{m}^{2} / \mathrm{m}$.y.) of organic constituents at Site 808 .

integration of TAI data with other indicators of organic maturity, such as vitrinite reflectance and geochemistry, and without consideration of the tectonic and burial history of the sediments, detailed modeling of the temperature history of Site 808 is beyond the scope of this paper. Therefore, the TAI data indicate a level in the middle of the mature stage of organic maturation at the bottom of Hole $808 \mathrm{C}$, which roughly corresponds to a maximum temperature range of about $100-150^{\circ} \mathrm{C}$. This range encompasses the predicted bottom-hole temperature based on shipboard data.

TAI analysis also does not show any significant increase in maturity of samples taken from within the frontal thrust and décollement zones, as compared to samples above and below those zones. If fluids significantly hotter than surrounding sediments had migrated along these fault zones, a signature of higher organic maturation might be expected from these zones. However, because of the time-dependent nature of organic maturation (Waples, 1980; Hood et al., 1975), short pulses of hot fluids on the order of hundreds to thousands of years in duration may not significantly affect organic matter in and adjacent to the fault zones. In the absence of any signature, three possibilities still exist: (1) no fluids have traveled along the fault zones; (2) fluids have traveled along the faults, but they were not significantly hotter than surrounding sediments; (3) hot fluids have migrated along the faults, but were of short duration, and did not alter the organic matter in the surrounding sediments. Therefore, the TAI analysis of the fault zones is largely inconclusive.

One of the unrealized objectives of Leg 131 was to investigate the effects of accretion and deformation on sediments by comparing Site 808 to a site drilled in the undeformed Shikoku Basin sediments seaward of the deformation front. This second site was not drilled, because poor drilling conditions neccesitated extension of the time spent at Site 808 to complete the objectives there. However, several 


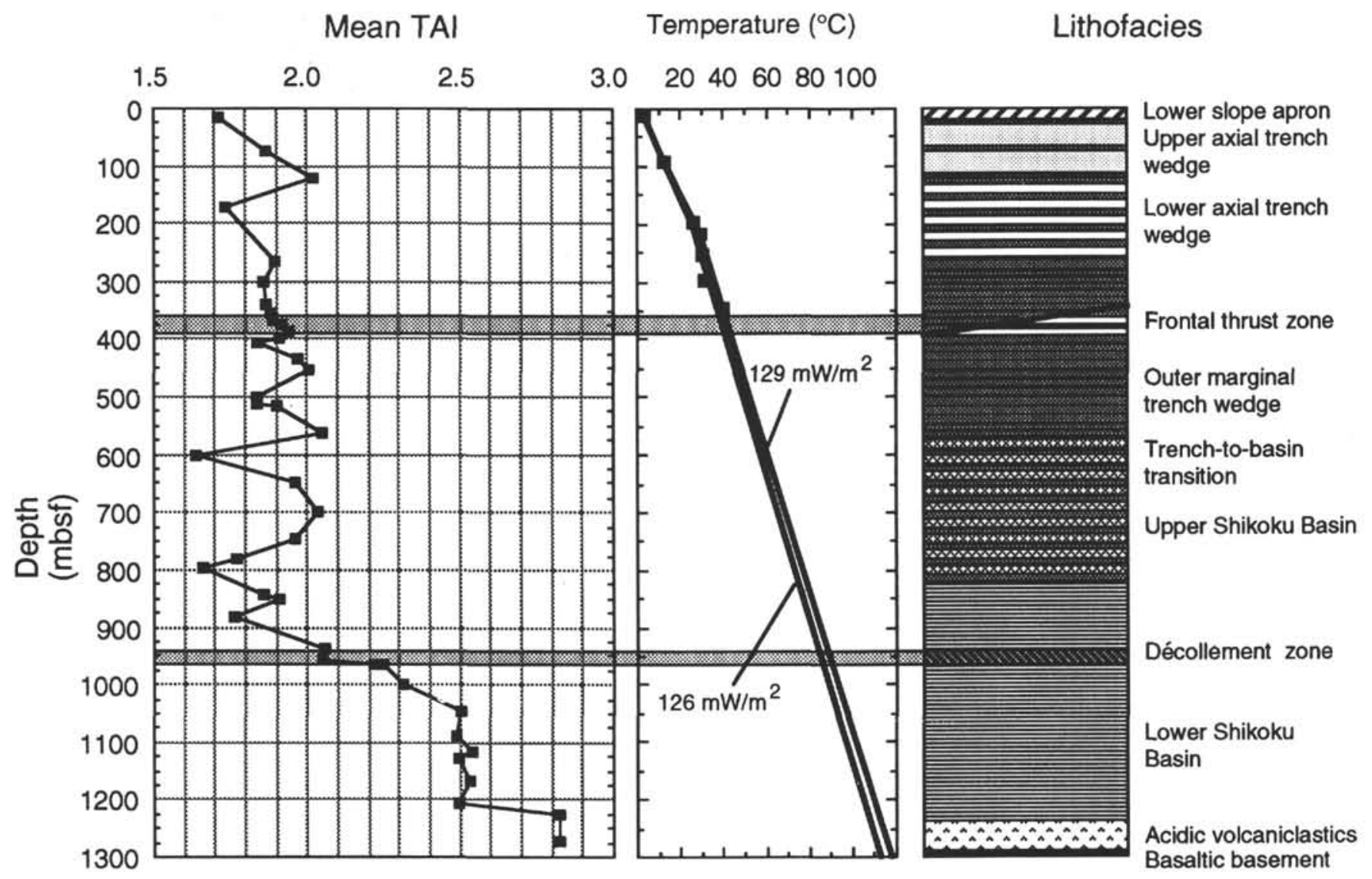

Figure 5. Mean numerical TAI values per sample, downhole temperature (WSTP), and calculated heat-flow values, and lithostratigraphy of Site 808 . Temperature, heat flow, and lithostratigraphy from Shipboard Scientific Party (1991).

other sites drilled in the Nankai Trough and Shikoku Basin during previous DSDP legs provide some comparisons to Site 808. Ames and Littlejohn (1975) determined that trench turbidite sediments as deep as $600 \mathrm{mbsf}$ at Site 298, and hemipelagites as deep as $430 \mathrm{mbsf}$ at Site 297, are immature. Mukhopadhyay et al. (1985) found a wide scatter of vitrinite and huminite reflectance values in sediments from Sites 582 and 583 in the Nankai Trough, which indicates a mix of both autochthonous vitrinite and reworked vitrinite. The recognizable autochthonous grains indicate immature levels down to $731 \mathrm{mbsf}$ (Pliocene hemipelagites) at Site 582 and down to 394 mbsf (Pleistocene turbidites) at Site 583. These results are consistent with data from Site 808. Rullkötter et al. (1980) concluded that nearly all organic matter from Shikoku Basin sediments drilled at Sites 442, 443, and 444 are reworked. Vitrinite reflectance measurements show a wide scatter of values and do not show any trend with depth. A few lightcolored spores or cuticles were observed that may indicate primary organic material and an immature stage of heating. This is the only data from the Shikoku Basin that can be compared with the lower hemipelagic sequence at Site 808 . If lower to middle Miocene sediments from the Shikoku Basin, at a depth of less than $350 \mathrm{mbsf}$, are immature, then the mature stage recorded by miospores in the lower to upper Miocene at Site 808 probably represents later heating of the sediments, perhaps as they neared the high heat-flow region of the Nankai Trough (Kinoshita and Yamano, 1986). Burial of these sediments below a thick turbidite sequence in the past 0.5 m.y. may also have contributed to the maturity of the deepest sediments. Unfortunately, no data exists from Miocene sediments just outside of the Nankai Trough, that have not yet been subjected to burial beneath the turbidites. Therefore, it is not known when the actual heating of the lower hemipelagites occurred - before or after turbidite deposition.

\section{CONCLUSIONS}

Palynofacies and thermal maturation analysis of sediments from Site 808 in the Nankai Trough indicate that:

1. Organic matter is predominantly of terrestrial origin and is composed primarily of reworked particles (inertite, miospores, poorly preserved and amorphous phytoclasts) and secondarily of primary organic matter (well-preserved phytoclasts and scleratoclasts, miospores). The reworked organic matter occurs in relatively constant amounts throughout the sequence from Shikoku Basin hemipelagites to trench turbidites. The abundance of well-preserved primary organic matter in palynologic Facies 1 distinguishes it from palynologic Facies 2.

2 . The high sedimentation rates and proximity to primary land plant sources of the trench turbidites are the reason for the abundance of well-preserved primary organic matter in Facies 1. Most of the poorly preserved organic matter in both Facies 1 and Facies 2 is reworked; however, the higher level of degradation in Facies 2 may be secondarily related to slower sedimentation rates, more chance of biodegradation and oxidation, and thermal maturation at depth.

3. Organic matter above the décollement is immature, whereas below the décollement there is a trend toward a moderate level of maturity ( $\left.3^{-}\right)$down to the basal sediments overlying basement. Samples from within the frontal thrust and décollement zones do not show significantly higher thermal maturation levels than sediments sur- 
Table 4. Sample depths and TAI values recorded for specimens of Impagidinium spp. from Hole 808C.

\begin{tabular}{cc}
\hline Depth (mbsf) & TAI values \\
\hline 780.3 & 2 \\
843.3 & 2,2 \\
935.1 & $2,2^{+}$ \\
957.3 & 2 \\
964.6 & $3^{-}, 3^{-}, 3^{-}$ \\
965.5 & $2^{+}, 2^{-}$ \\
1088.5 & $2,3^{-}, 3^{-}$ \\
1117.8 & $2^{+}, 2^{+}$ \\
1127.9 & $2^{+}$ \\
1166.0 & $2^{+}, 3^{-}, 3^{-}$ \\
1205.3 & $2^{+}, 3^{-}$ \\
1224.4 & 3 \\
1271.8 & $3^{-}, 3$ \\
\hline
\end{tabular}

rounding these zones, which suggests that any fluids that may have migrated along these zones were probably not significantly hotter than the surrounding sediments. Samples within and just above the basal acidic tuffs show the highest degree of maturation, significantly higher than overlying samples. This may be related to the high thermal conductivity values of the tuffs and the proximity to basement.

\section{ACKNOWLEDGMENTS}

This research was accomplished with support from a USSAC Grant. John Jones of the Texas A\&M Palynology Lab processed the samples for this study.

\section{REFERENCES}

Ames, R.L., and Littlejohn, R., 1975. Diagenesis of organic matter and estimated temperature history from carbonization measurements, Shikoku Basin. In Karig, D.E., Ingle, J.C., Jr., et al., Init. Repts. DSDP, 31: Washington (U.S. Govt. Printing Office), 621-627.

Fisher, A.T., and Hounslow, M.W., 1990. Heat flow through the toe of the Barbados accretionary complex. In Moore, J.C., Mascle, A., et al., Proc. $O D P$, Sci. Results, 110: College Station, TX (Ocean Drilling Program), 345-363.

Habib, D., 1979. Sedimentary origin of North Atlantic Cretaceous palynofacies. In Talwani, M., Hay, W., Ryan, W.B.F. (Eds.) Deep Drilling Results in the Atlantic Ocean: Continental Margins and Paleoenvironment. Am. Geophys. Union, Maurice Ewing Ser., 3:420-437.
Habib, D., and Miller, J.A., 1989. Dinoflagellate species and organic facies evidence of marine transgression and regression in the Atlantic Coastal plain. Palaeogeogr., Palaeoclimatol., Palaeoecol., 74:23-47.

Hart, G.F., 1986. Origin and classification of organic matter in clastic systems. Palynology, 10:1-23.

Heroux, Y., Chagnon, A., and Bertrand, R., 1979. Compilation and correlation of major maturation indicators. AAPG Bull., 63:2128-2144.

Hood, A., Gutjahr, C.C.M., and Heacock, R.L., 1975. Organic metamorphism and the generation of petroleum. AAPG Bull., 59:986-996.

Kinoshita, H., and Yamano, M., 1986. The heat flow anomaly in the Nankai Trough area. In Kagami, H., Karig, D.E., Coulbourn, W.T., et al., Init. Repts. DSDP, 87: Washington (U.S. Govt. Printing Office), 737-743.

Martini, E., 1971. Standard Tertiary and Quaternary calcareous nannoplankton zonation. In Farinacci, A. (Ed.), Proc. 2nd Planktonic Conf. Roma, Rome (Ed.Technosci.), 2:739-777.

Mukhopadhyay, P.K., Rullkötter, J., Schaeffer, R.G., Welte, D.H., 1985. Facies and diagenesis of organic matter in Nankai Trough sediments, Deep Sea Drilling Project Leg 87A. In Kagami, H., Karig, D.E., Coulbourn, W.T., et al., Init. Repts. DSDP, 87: Washington (U.S. Govt. Printing Office), 877-889.

Pearson, D.L., 1984. Pollen/spore color "standard." Phillips Petrol. Comp., Bartlesville, OK, Version 2.

Rullkötter, J., Flekken, P., and Welte, D.H., 1980. Organic petrography and extractable hydrocarbons of sediments from the northern Philippine Sea, Deep Sea Drilling Project Leg 58. In Klein, G. deV., Kobayashi, K., et al., Init. Repts. DSDP, 58: Washington (U.S. Govt. Printing Office), 755-762.

Shipboard Scientific Party, 1991. Site 808. In Taira, A., Hill, I., Firth, J.V., et al., Proc. ODP, Init. Repts., 131: College Station, TX (Ocean Drilling Program), 71-272.

Stach, E., Mackowsky, M.-T., Teichmüller, M., Taylor, G.H., Chandra, D., and Teichmüller, R., 1982. Stach's Textbook of Coal Petrology (3rd Ed.): Berlin (Gebruder Borntraeger).

Staplin, F. L., 1969. Sedimentary organic matter, organic metamorphism, and oil and gas occurrence. Bull. Can. Pet. Geol., 17:47-66.

Taira, A., Hill, I., Firth, J.V., et al., 1991. Proc. ODP, Init. Repts., 131: College Station, TX (Ocean Drilling Program).

Waples, D.G., 1980. Time and temperature in petroleum formation: application of Lopatin's method to petroleum exploration. AAPG Bull., 64:916-926.

Wrenn, J.H., and Kokinos, J.P., 1986. Preliminary comments on Miocene through Pleistocene dinoflagellate cysts from De Soto Canyon, Gulf of Mexico. In Wrenn, J.H., Duffield, S.L., and Stein, J.A. (Eds.), Papers from the 1st Symp. on Neogene Dinoflagellate Cyst Biostratigraphy. AASP Contrib. Ser., 17:169-226.

Date of initial receipt: 26 September 1991

Date of acceptance: 8 May 1992

Ms 131SR-101 

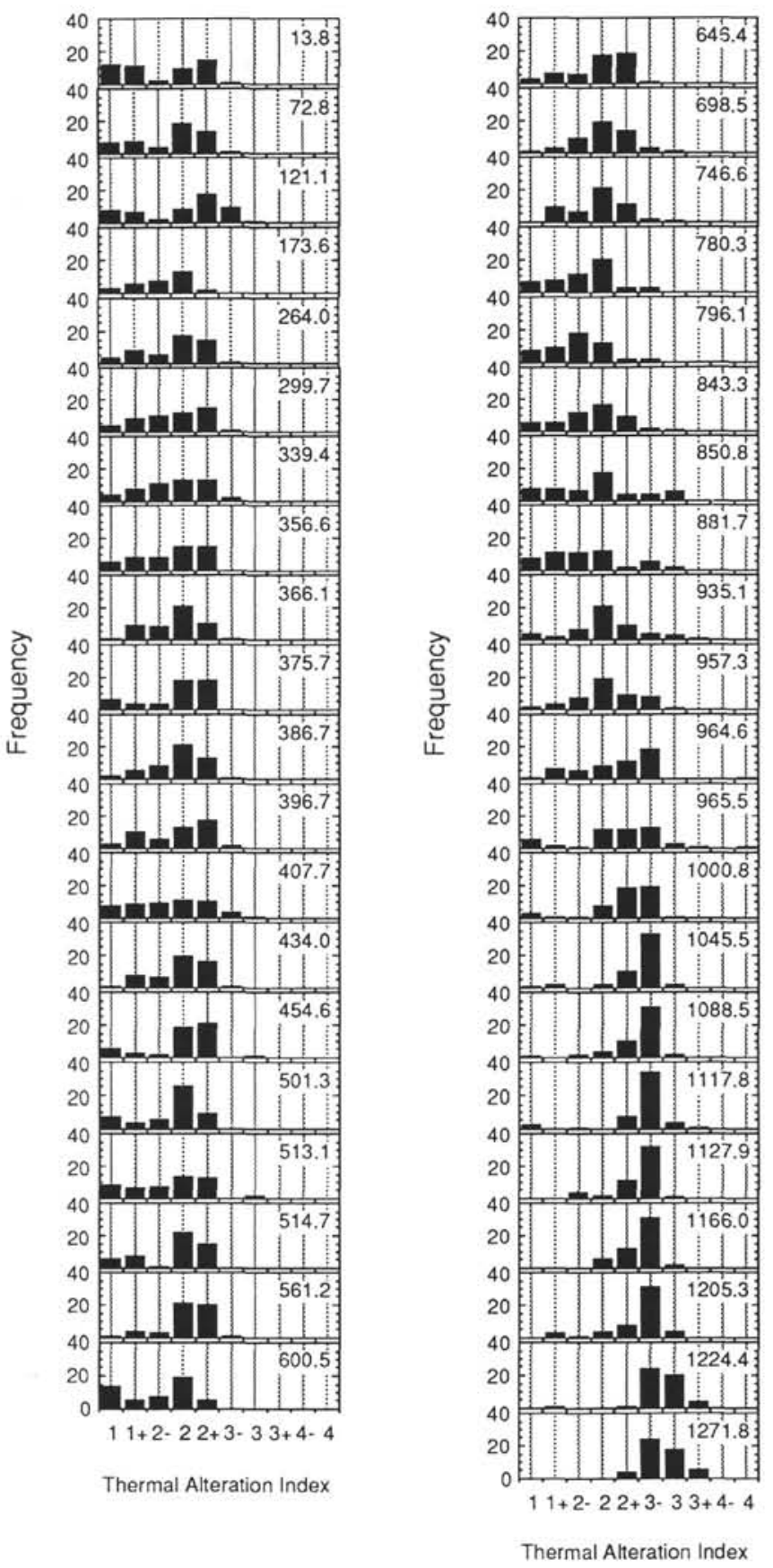

Figure 6. Histograms of TAI values determined from pollen and spores in samples from Site 808. Numerals in top right of each histogram refer to depth of each sample (mbsf). 

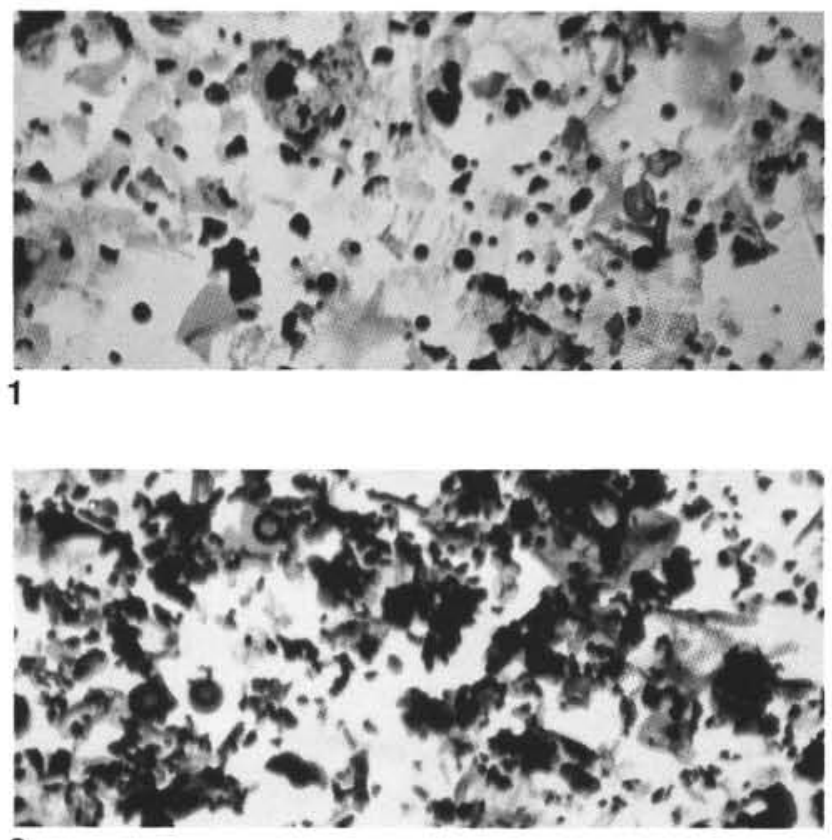

3

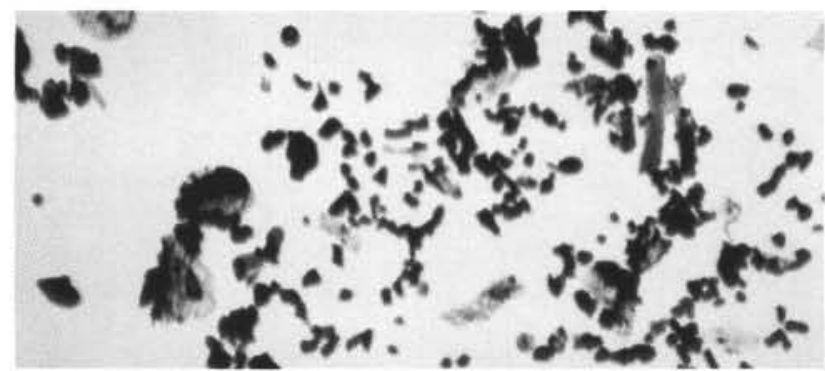

5

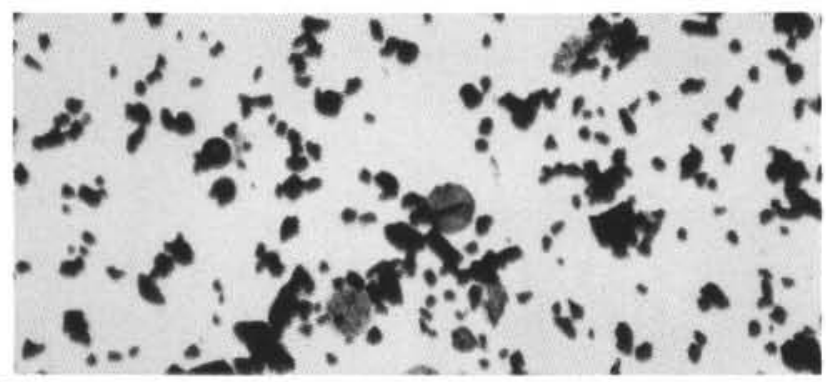

7

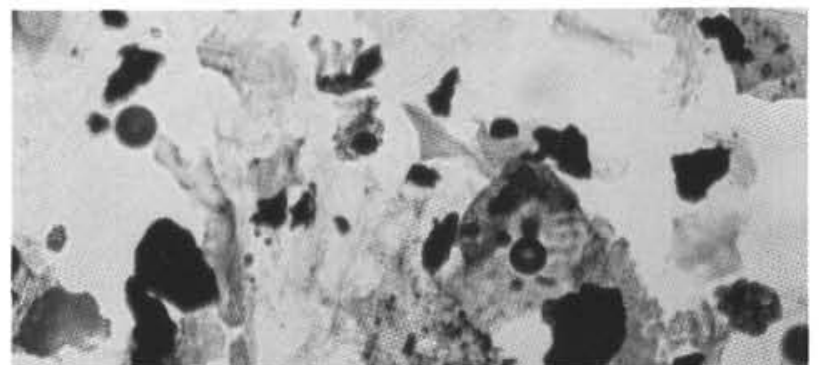

2
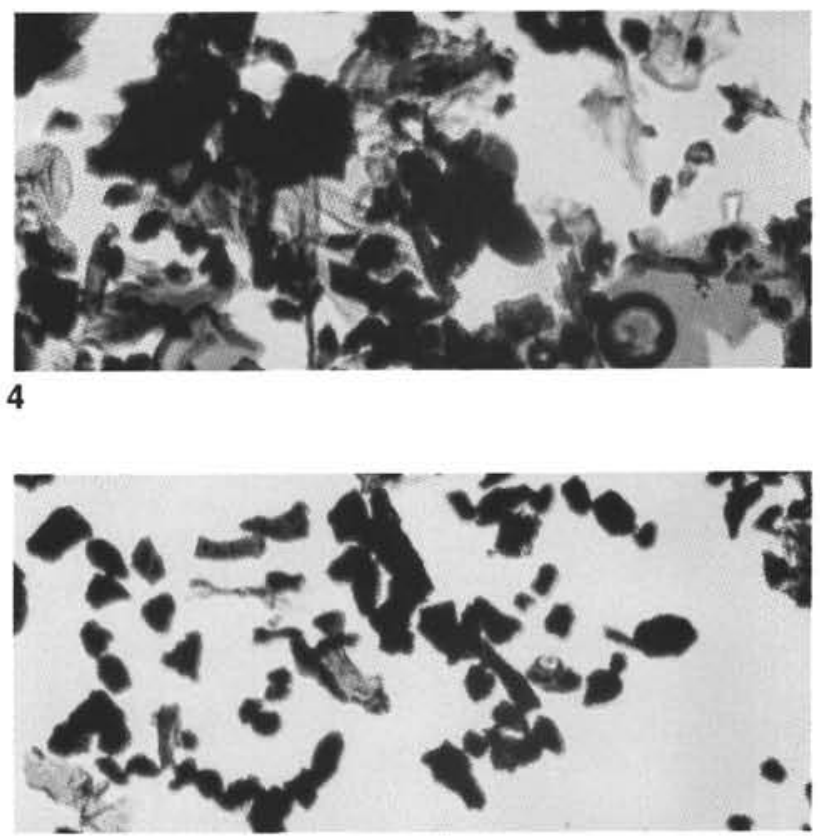

6

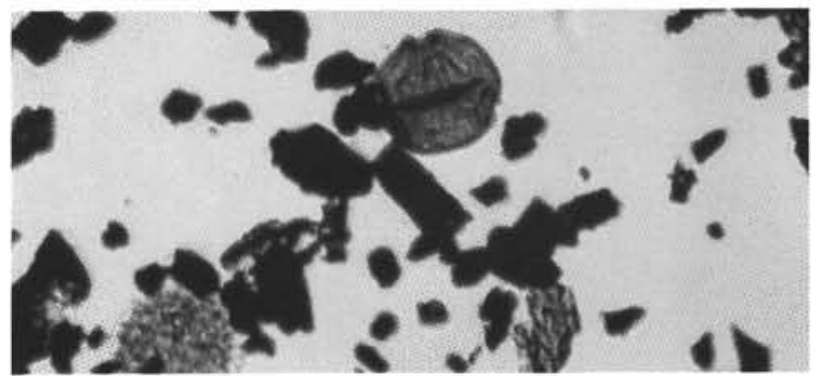

8

Plate 1. Palynofacies of the Nankai Trough turbidite and hemipelagite sequences. 1. Facies 1, note mix of large phytoclasts and small inertite, Sample 131808A-9H-4, 3-5 cm. 2. Close-up of figure 1. 3. Facies 1, Sample 131-808C-15R-1, 28-30 cm. 4. Close-up of figure 3. 5. Facies 2, note predominance of inertite, Sample 131-808C-57R-4, 70-72 cm. 6. Close-up of figure 5. 7. Facies 2, Sample 131-808C-98R-1, 67-69 cm. 8. Close-up of figure 7. 1, 3, 5, 7: Magnification 160×. 2, 4, 6, 8: Magnification 400x. 


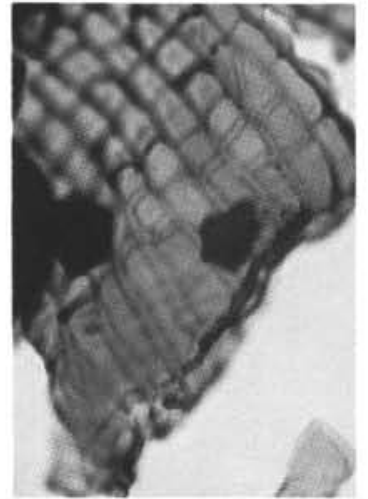

1

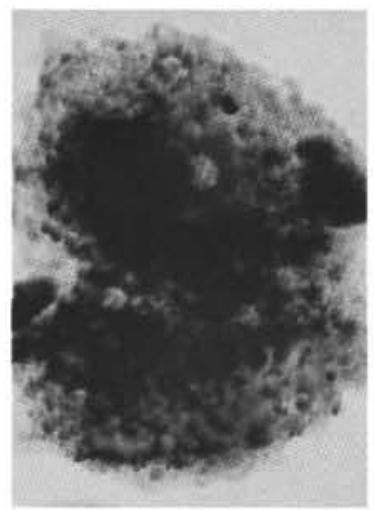

5

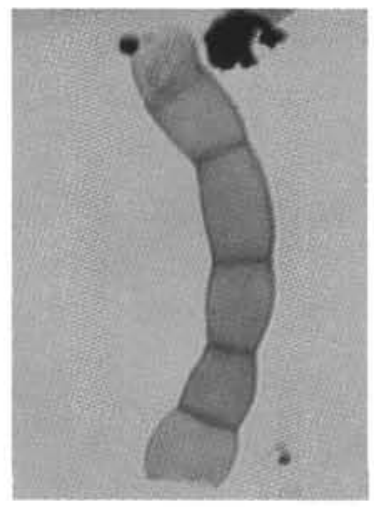

9

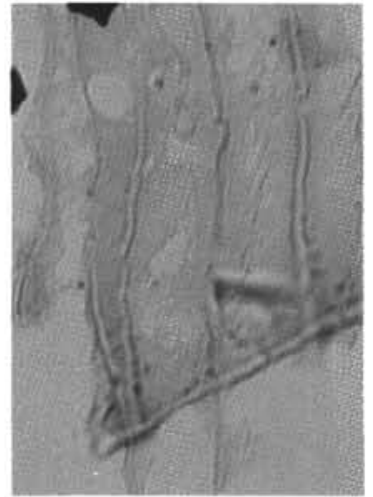

2

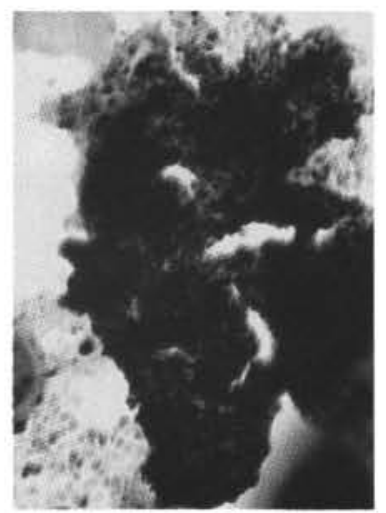

6

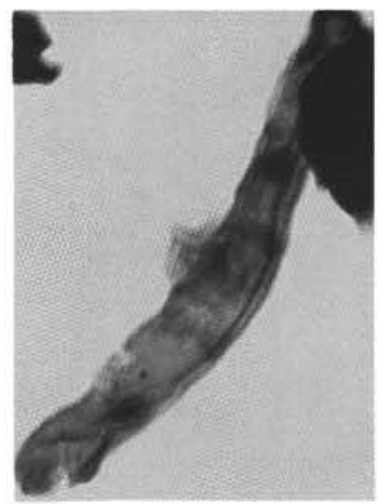

10

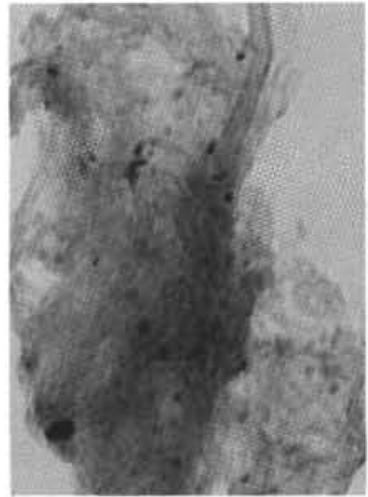

3

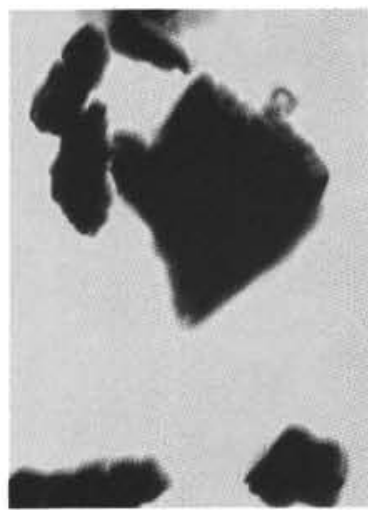

7

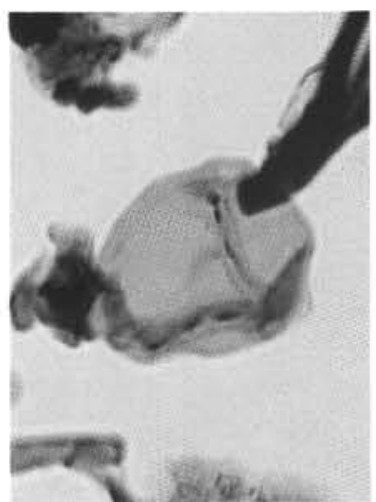

11

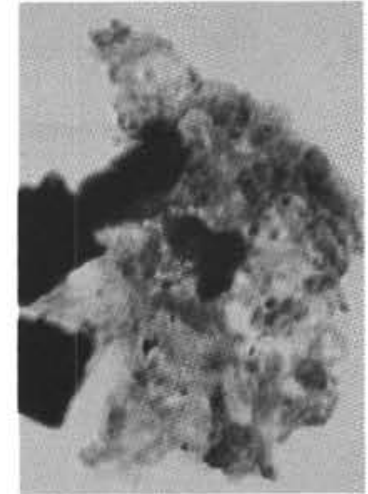

4

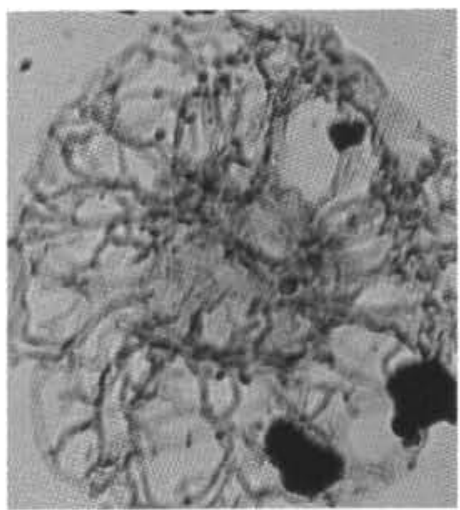

8

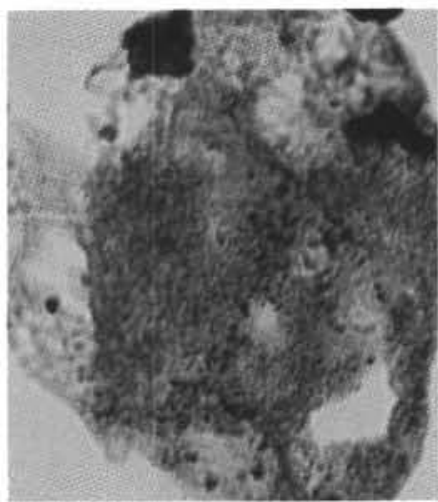

12

Plate 2. Organic constituents used in classification scheme. 1. Well-preserved phytoclast, Sample $131-808 \mathrm{C}-28 \mathrm{R}-2,78-80 \mathrm{~cm}$. 2. Poorly preserved phytoclast, Sample 131-808C-12R-3, 8-10 cm. 3. Amorphous organic matter, Sample 131-808C-12R-3, 8-10 cm. 4. Amorphous organic matter, Sample 131-808C-50R-1, 15-17 cm. 5. Amorphous organic matter, Sample 131-808C-50R-1, 15-17 cm. 6. Amorphous organic matter, Sample 131-808C-8R-1, 23-25 cm. 7. Inertite, Sample 131-808C-8R-1, 23-25 cm. 8. Dinoflagellate cyst (Nematosphaeropsis lemniscata), TAI = 3-, Sample 131-808C-98R-1, 67-69 cm. 9. Well-preserved scleratoclast, Sample 131-808A-2H-6, 5-7 cm. 10. Poorly preserved scleratoclast, Sample 131-808C-28R-2, 78-80 cm. 11. Well-preserved miospore, Sample 131-808C-28R-2, 78-80 cm. 12. Poorly preserved miospore, Sample 131-808C-103R-1, 90-92 cm. All photographs 1008×. 


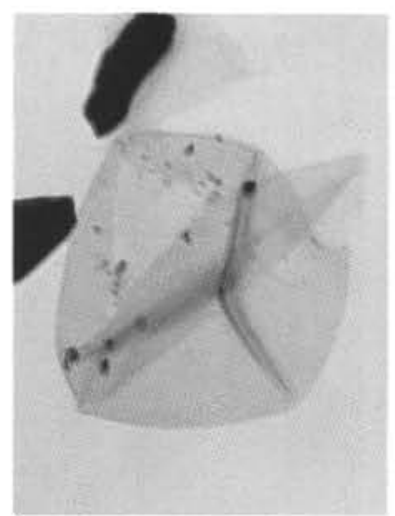

1

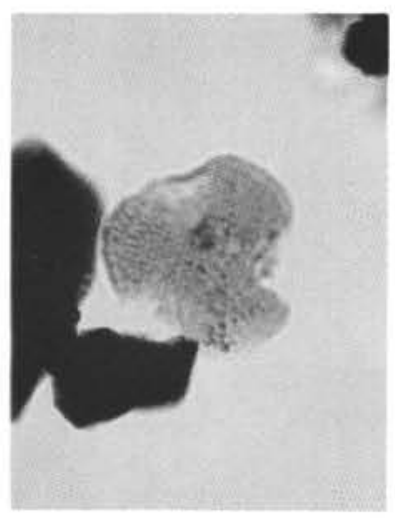

5

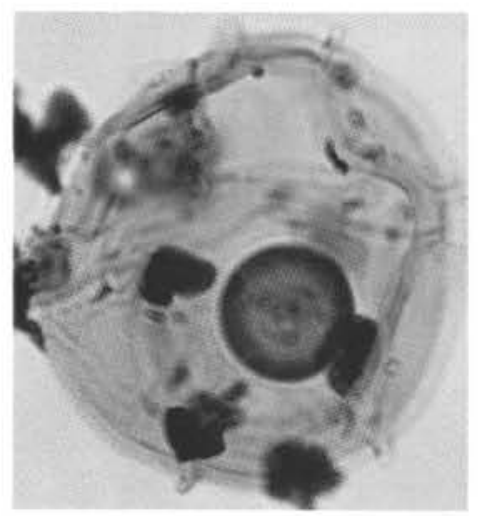

9
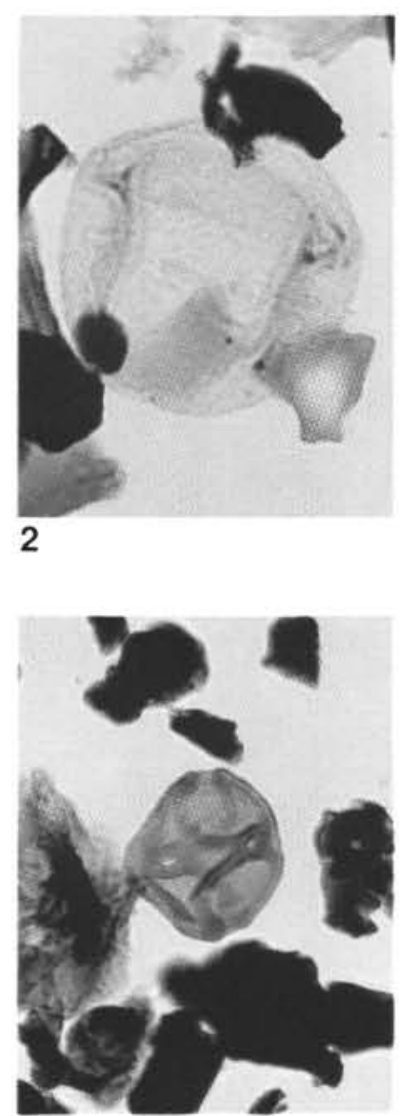

6

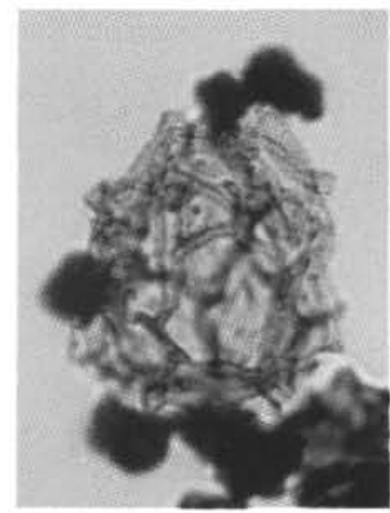

10

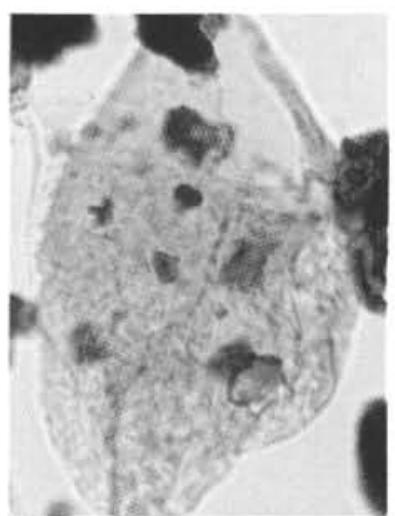

3

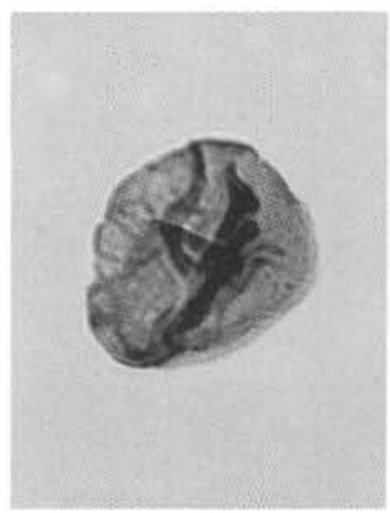

7

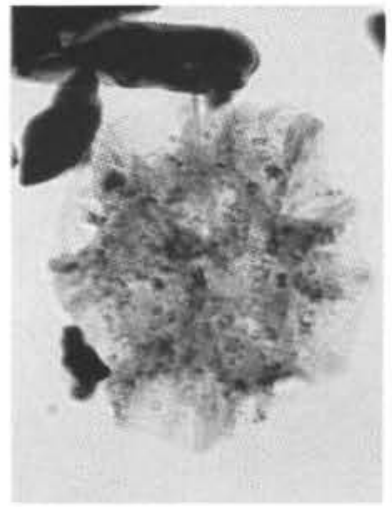

11

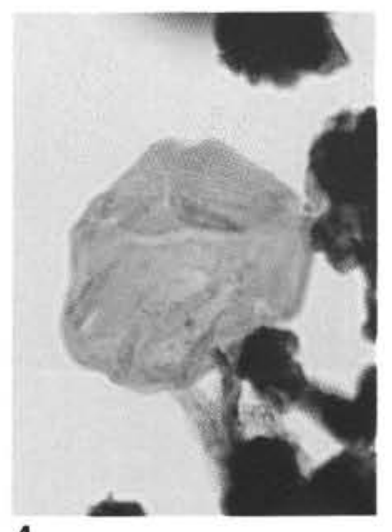

4

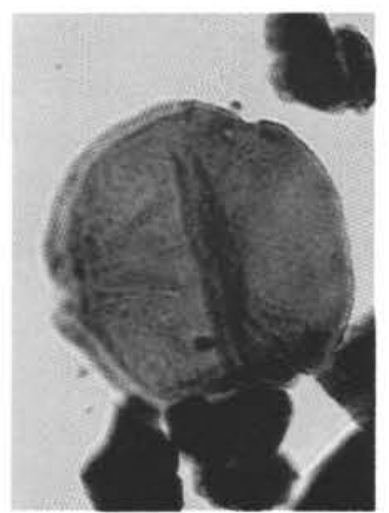

8

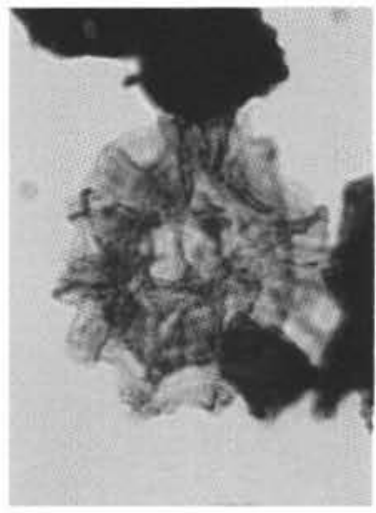

12

Plate 3. Miospores (1-8) and dinoflagellate cysts (Impagidinium spp., 9-12) showing different colors due to thermal alteration. 1. TAI =1, Sample 131-808A$2 \mathrm{H}-6,5-7 \mathrm{~cm}$. 2. $\mathrm{TAI}=1^{+}$, Sample 131-808A-2H-6, 5-7 cm. 3. TAI $=2^{-}$, Sample 131-808C-52R-5, 28-0 cm. 4. TAI = 2, Sample $131-808 \mathrm{C}-92 \mathrm{R}-1,42-45$ cm. 5. $\mathrm{TAI}=2^{+}$, Sample $131-808 \mathrm{C}-50 \mathrm{R}-1,15-17 \mathrm{~cm} . \quad$ 6. $\mathrm{TAI}=3^{-}$, Sample $131-808 \mathrm{C}-98 \mathrm{R}-1,67-69 \mathrm{~cm} . \quad$ 7. TAI $=3$, Sample $131-808 \mathrm{C}-98 \mathrm{R}-1,67-69 \mathrm{~cm}$. 8. $\mathrm{TAI}=3^{+}$, Sample 131-808C-98R-1, 67-69 cm. 9. TAI $=2$, Sample 131-808C-57R-4, 70-72 cm. 10. TAI =2 + , Sample 131-808C-83R-2, 114-117 cm. 11 . $\mathrm{TAI}=3^{-}$, Sample 131-808C-83R-2, 114-117 cm. 12. TAI = 3, Sample 131-808C-98R-1, 67-69 cm. All photographs $1008 \times$. 


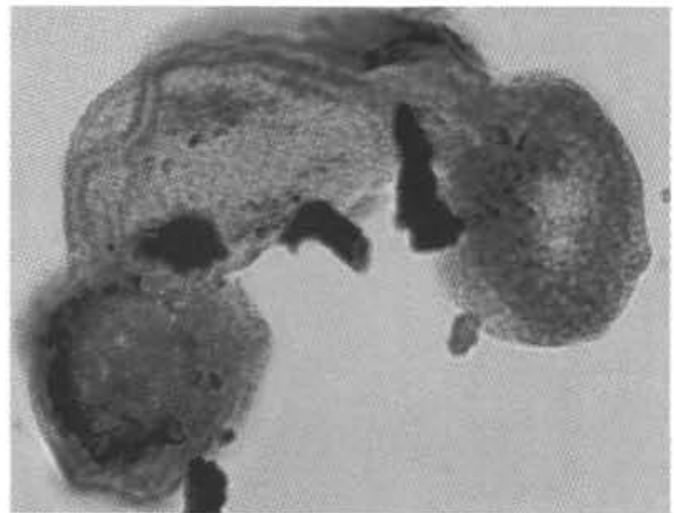

1

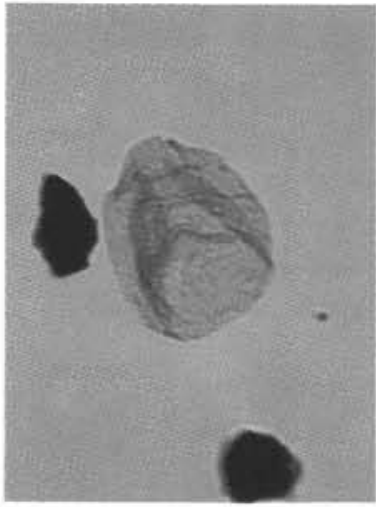

4

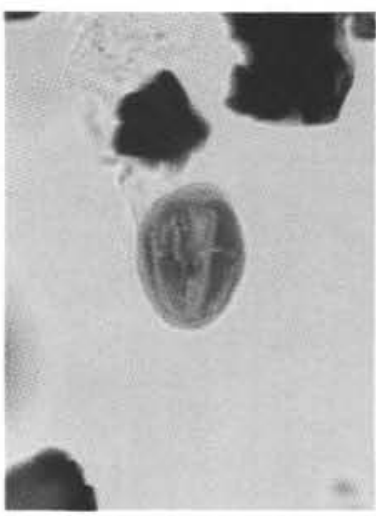

8

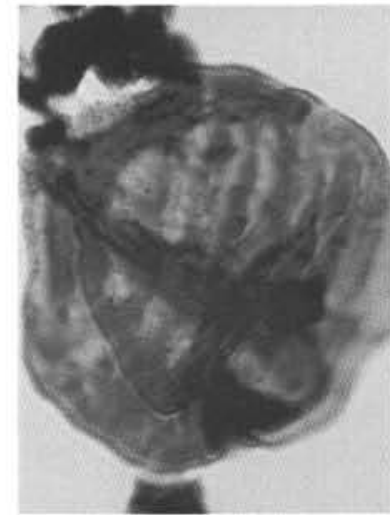

2

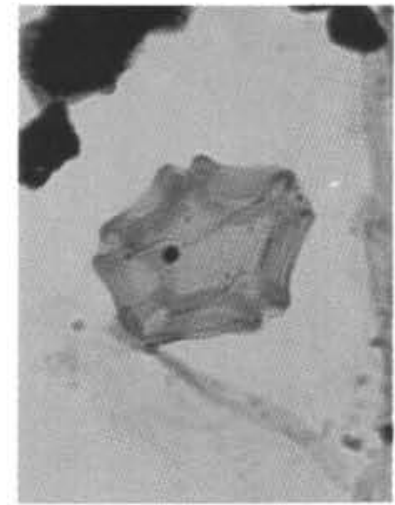

6

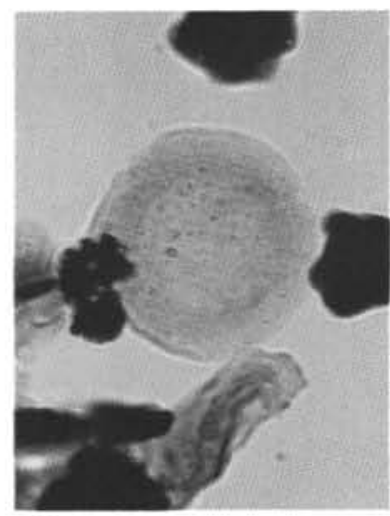

10

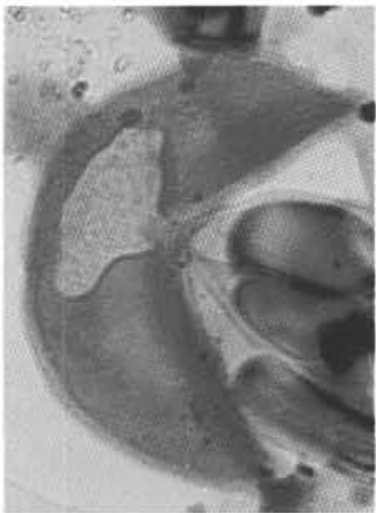

3

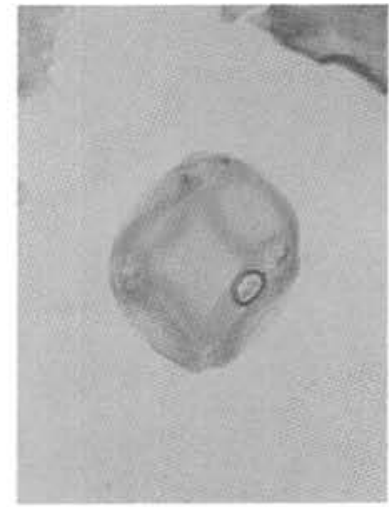

7

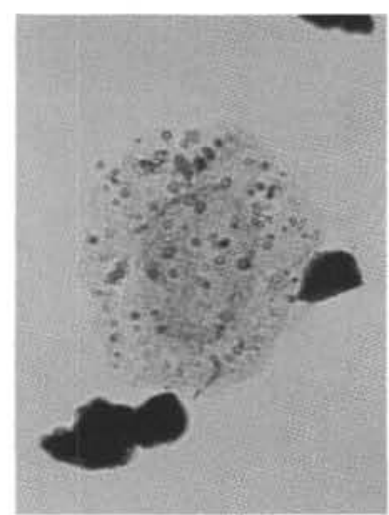

11

Plate 4. Selected miospores (1-9) and algal cysts (10-11, aff. Pterospermella? spp.) from Nankai Trough sediments. 1. Bisaccate pollen, TAI $=2^{+}$to 3 , Sample 131-808C-8R-1, 23-25 cm. 2. Cicatricose spore, TAI $=2^{+}$to $3^{-}$, Sample 131-808C-87R-1,23-27 cm. 3. Split inaperturate pollen, TAI $=2^{+}$, Sample $131-$ 808A-2H-6,5-7 cm. 4. Granular spore, TAI $=3^{-}$to 3?, Sample 131-808C-98R-1, 67-69 cm. 5. Verrucate monocolpate pollen, TAI =3-, Sample 131-808C-92R-1, $42-45 \mathrm{~cm}$. 6. Pentaporate arci pollen, $\mathrm{TAI}=3^{-}$?, Sample $131-808 \mathrm{~A}-2 \mathrm{H}-6,5-7 \mathrm{~cm}$. 7. Quadraporate arci pollen, TAI $=1$ to $1^{+}$?, Sample $131-808 \mathrm{C}-28 \mathrm{R}-2,78-80 \mathrm{~cm}$. 8. Tricolporate pollen, $\mathrm{TAI}=3^{-}$, Sample $131-808 \mathrm{C}-92 \mathrm{R}-1,42-45 \mathrm{~cm}$. 9. Triporate pollen, $\mathrm{TAI}=2$ to $2^{+}$, Sample $131-808 \mathrm{C}-28 \mathrm{R}-2,78-80 \mathrm{~cm}$. 10. Algal cyst, Sample 131-808C-83R-2, 114-117 cm. 11. Algal cyst, Sample 131-808C-83R-2, 114-117 cm. All photographs 1008×. 